\title{
The function of the Easter moment in the observance of the Eucharist amongst Christian communities framed by traditional African and current Western time-concepts
}

\author{
Authors: \\ Rantoa S. Letšosa ${ }^{1}$ \\ Fritz W. De Wet ${ }^{1}$ \\ Ben J. De Klerk ${ }^{1}$

\section{Affiliations:} \\ ${ }^{1}$ School for Ecclesiastical \\ Sciences, Faculty of Theology, \\ North-West University, \\ South Africa

\section{Correspondence to:} \\ Rantoa Letšosa \\ Email: \\ Rantoa.letsosa@nwu.ac.za \\ Postal address: \\ PO Box 20679, Noordbrug \\ 2522, South Africa \\ Dates: \\ Received: 28 Oct. 2010 \\ Accepted: 04 Aug. 2011 \\ Published: 07 Nov. 2011 \\ How to cite this article: \\ Letšosa, R.S., De Wet, F.W. \\ \& De Klerk, B.J., 2011, \\ 'The function of the Easter \\ moment in the observance \\ of the Eucharist amongst \\ Christian communities \\ framed by traditional African \\ and current Western time- \\ concepts', Verbum et Ecclesia \\ 32(1), Art. \#474, 8 pages. \\ http://dx.doi.org/10.4102/ \\ ve.v32i1.474
}

(C) 2011. The Authors. Licensee: AOSIS OpenJournals. This work is licensed under the Creative Commons Attribution License.
Problematic elements in both the traditional African and current Western time-concepts seem to manifest in a manner that - in some or other way - causes humanity to become disconnected with the fulfilment of life in a future destiny that breaks through the entrapment of the perpetual present and cyclical past. In their research, the authors asked in what sense and to what extent time concepts can hinder the Christian worshipper in anchoring his or her life in the consummating, witness-energising power of communion with the living, timetransforming Christ and faith in the imminence of his return. In addressing this research problem, key elements in traditional African and current Western time conceptualisation were described, as well as the role of the Easter moment (as it manifests in the observance of the Eucharist) in transforming problematic elements in these particular manifestations of time conceptualisation. In conclusion, preliminary theoretical anchors were formulated for the function of the observance of the Eucharist and its role in transforming various enslaving and disconnecting aspects of cultural time conceptualisation.

\section{Introduction}

Concepts regarding time, and the historical consciousness that flows from it, have a definitive influence on the quality and purpose of human life. Distortions in time concepts can severely impede one's sense of purpose and engagement in activities that could really make a difference in people's lives. Being wearied by a constant battle against the clock and disillusioned by a sense that time will eventually undo the possibility of producing any lasting effects with one's life, could eventually lead to despondency and a loss of purpose.

Historical consciousness flowing from time concepts formed in both traditional African and current Western contexts seems to be, in some way or another, mutually disconnected with the fulfilment of life in a future (eternity) that breaks through the entrapment of the perpetual present and cyclical past. The influence of time conceptualisation in cultural life may estrange Christians from the liberating and life-consummating power that - in our view - flows from biblical concepts regarding time. This may result in an inability to deliver the much needed prophetic witness regarding consummation to a world seemingly caught up in a perpetual or cyclical pattern of life senselessly withering away until death.

The research problem then centres on the following question: in what sense and to what extent can time concepts (as manifested in traditional African and current Western contexts) hinder the Christian worshipper in anchoring his or her life in the consummating, witness-energising power of communion with the living, time-transforming Christ and faith in the imminence of his return? In addressing this research problem, it should also be asked what role could a new view on the function of Christian rituals (such as the observance of the Eucharist) play in transforming problematic time concepts and the impeded historical consciousness that flows from these concepts.

This research intends to determine in what sense and to what extent the act of honouring elements of time, as expressed in the Easter moment, may be seen as an important liturgical tool in activating the fullness of life that God intended for his people and for the world in which they live. To this end, we undertake the following in this paper:

- A brief exploration of the perspectives on the traditional African time-concept, as well as those of the current Western time-concept.

- An investigation of the biblical vision of time and the Easter moment embedded in the ritual of the Eucharist.

- The formulation of preliminary theoretical anchors for the function of the observance of the Eucharist in transforming problematic aspects of African and Western time-concepts. 


\section{Perspectives on the time concept in a traditional African context}

\section{Mbiti's view regarding the traditional African time-concept}

In his monumental work African religion and philosophy, John Mbiti (1969:15) proposes the African concept of time as the key to our understanding of the basic religious and philosophical concepts' of the African 'ontology'. Yet, at the same time, the African concept of time can only be understood properly within the African ontology. Despite the fact that not many philosophers agreed with his explanation of the African concept of time, there are those who support him, such as Kagame (1996). Mbiti speaks of a two-dimensional view of time: a long past, a present and practically no concept of future (see Van der Walt 2003:162). Mbiti (1969) further highlights seven notions of time within the traditional African frame of reference:

- That traditional African people are moving backward in time, towards the past, which they are gradually entering and becoming part of.

- That time is inseparable from that of the dead. The place to where traditional African people are moving is full of real people, the spirits of the departed.

- That time is essentially relational. Traditional African people always stand in relation to the departed, even in this life. Their relationship to the deceased, especially close relations, is ongoing and permanent.

- That there are various forms of interaction between the living and the dead and various ways in which this relationship is expressed.

- That the world of the dead is divided into two spheres: the first being of known ancestors who are still remembered (Sasa) and the second of ancestors who died long ago and who are not known by the immediate family still alive (Zamani).

- Those ancestors are from the immediate background and horizon of the African people, because the living are moving backwards towards them. Ancestors are very powerful; from the past, they determine one's well-being in the future. Thus, for the African, time is something concrete and not empty - it is inseparable from a specific place or event.

- That the individual should not be understood in an individualistic manner but rather in a social manner as one belonging to a group. The individual has a responsibility towards the group to which he or she belongs.

\section{Implications and effects of the traditional African time-concept on the historical consciousness of traditional communities}

Events are made by people and, even if they are simply natural phenomena, they affect people in certain ways. As such, one may conclude with Van Zyl (2007:142) that time is a space filled with people in which human relationships are the controlling factor in all that happens. Similarly, Mbiti (1969:17) states that time is simply a composition of events: those which have occurred, those that are taking place now and those that would occur in the immediate future. Van Zyl (2007:143) summarises the African concept of time in the following manner:

- Traditional African time is humanistic because it depends on meaningful events in the ordinary existence of a community from birth to death.

- It is social, democratic and phenomenological because it relates to the activities and concerns of living human beings. This means that African time is not philosophical or abstract.

- It is calculated in terms of natural events in the life of the community; hence, it is also not mathematical.

In his table of comparison, Van der Walt (2003:169-170) adds a few additional aspects, of which only some are indicated here because of relevance. He (ibid.) adds that each moment in the African concept is unique, heterogeneous and qualitative. It is not a matter of clock-time, but there are different types of time, which is more than that which is expressed in numbers. Time is cyclical and therefore repetitive, without any beginning or end. Time is also kairological, elastic and flexible. There is no need for punctuality and planning because it is abundant and any extra time needed can be made. Time should be enjoyed because it is a servant to the African and not a master.

Nyirongo (1993:90) also produces a summary of implications of the two-dimensional traditional African time-concept. Traditional African people have a limited eschatological vision, or an inverted eschatology: the African looks forward to joining the past. They live in the present but remain oriented to the past because the best things are in the past. They are unwilling to leave the old things and the past and thus have great respect for, and abound to, the past. Order and continuity also play an essential role. Nyirongo adds that traditional Africans do not mind waiting and consequently lack motivation. Nyirongo's (1997:91) critique on this view is that African people are not looking forward to paradise or utopia in the Western, Christian sense. Their paradise is the Zamani period, as it incorporates what they believe to be the best way of living. The purpose for African people in the present life is to acquire as much life force as possible in order to be able to live in the past. Africans have to live well with their ancestors in order to find fulfilment and, as a result, this kind of living makes them too occupied with the past (Nyirongo 1997:93).

Mbiti's observation that, in an African worldview, one moves to the 'future' facing backwards towards the 'past' correlates with certain parts of the Old Testament, where there is apparently no interest in the future and, particularly, for life beyond death. Apart from a few exceptions, there is apparently no interest in the Old Testament for a reality which lies beyond this concrete world. The expectations of a better future, introduced by some prophets, mostly deal with this earthly life. In African ontology 'those beyond' (abangasekhoyo) are part of this earthly reality (Sasa) - at least for as long as they are remembered. Hence, as Turaki (1993:25-26) states, the world of the ancestors for the 
traditional African is the best, closest thing to the perfect origin and therefore has more potency than the present and much less than the future. What the ancestors have passed down must be maintained, preserved, protected and consequently passed down to the next generation.

\section{Two problematic elements in the traditional African time-concept}

The brief exploration of current trends in traditional African time-conceptualisation and its impact on the human mind highlights two key issues that may be relevant in addressing our research question:

- To what extent may the humanistic orientation of preoccupation with ancestors that have passed away in death, undergo transformation by means of living communion with Christ in the Easter moment? In other words, to what extent may backward preoccupation with death be transformed into forward preoccupation with life?

- In what manner can the past-oriented, cyclical perspective of time be amended by participation in the Easter moment to focus more on, and be motivated by, the eschatological fulfilment of life in the new creation of God in all its eternal joy and fullness?

\section{Perspectives on the time concept in current Western culture \\ The implications of moving from modernity to postmodernity}

Modern conceptions of time that have led to its commodification can - in our view and amongst other factors - be traced to the period of transition between the Middle Ages and modernity. Time was no longer thought of as qualitatively determined by a divine plan but as quantitatively constructed in an unvarying linear progression. In this modern view, history is 'additive'; the whole is no more than the sum of its parts. History writing merely arranges events 'like the beads on a rosary' and 'contents itself with establishing a causal connection between various moments in history' (Bader-Saye 2006:93). By secularising time, the range of temporal qualities are reduced to the monotony of clock time. Where this concept of time takes hold, no space can be given for the inclusion of 'un-exact' and 'metaphysical' elements such as the possibility of divine interruption, the stopping of time, the purification of time, a new beginning or final end and consummation (cf. Kepnes 2006:115). In this conceptualisation, time is reduced to the bare dimension of quantity, where actions taking place in time and space can be measured exactly; a conceptualisation ideally suited to the controlled environment needed for the scientific endeavours of positivism that describes its findings in absolutist terms.

Although modernity eschewed any theological framework for understanding time and history, it still presupposed that we inhabit a narratable and explainable world. The Enlightenment fed Western culture with optimistic visions of human progress. But in the wake of the 20th century, the deadliest century to date, this story of inevitable progress strikes one as untenable and even perverse. Indeed, for many 'postmoderns', the very idea that world events hold together as a coherent narrative seems overly optimistic. Thus, whilst modernity gave us a story without an author, postmodernity has given us a world without a story. Without an overarching narrative in which the self might locate an enduring identity, the smaller narratives of human lives easily become fragmented into dislocated moments. All moments become interchangeable. In contrast to Enlightenment faith in progress, postmodern 'history' becomes a book you read in reverse, so you understand less as the pages turn (Bader-Saye 2006:94). The influence of postmodern thought on culture asks a growing flexibility of the 'nuclear man' as Nouwen (1972:10) defines the Western human of late modernity - and a willingness to remain open and live with the small fragments which, at the moment, seems to offer the best response to a given situation. 'Nuclear man' no longer believes in anything that is always and everywhere true and valid. He lives by the hour and creates his life on the spot.

The 'flexibility' and 'willingness to remain open' mentioned by Nouwen may - in our view - indeed open the Western mind for gestural elements in the conceptualisation of time and may enable humanity to view time not only quantitatively but also qualitatively. When time is not only defined in an absolute sense (time that needs to be measured) but also in a gestural sense (time as something that can be experienced), insight can be revealed regarding the possibility of having a richer view on a temporal life that is not simply determined by the clock (cf. Olsen 2006:311). However, it is also evident that the flexibility of postmodernity easily may let a person drift and lose coherence in life and the unfolding of its events, its purpose and its consummation. Goheen (2008:114) writes that ours is a culture in search of meaning. The fragmentation that postmodernity has visited on our culture, leaves Western culture increasingly without a robust centre from which to draw its meaning and practices. Postmodernity has reduced the grand story of modernity to 'a heap of broken images', mere disconnected fragments.

\section{The effect that current manifestations of time concepts may have on the historical consciousness of the Western mind}

In theorising on the effect of time conceptualisation on the historical consciousness of the Western mindset, it should be noted - in our view - that the impact of postmodern 'chaos' did not replace the 'order' of modernity; rather, it is a case of the two becoming indistinguishable. The homogenous, empty time ushered in by the modern era continues to reign supreme, but now without the optimistic assumption that human beings could imprint order on its pristine sands (Bader-Saye 2006:94). Let us now, for a moment or two, ponder the lingering effect of a conceptualisation of measured time operating in an undisturbed, linear framework on the Western historical consciousness and, thereafter, on the possible effects of the fragmentary elements introduced by postmodernity. 


\section{An historical consciousness entrapped by the exacting monotony of the clock}

Nouwen (1972:9) shows how Western human beings came to think of themselves as passive victims of an extremely complex technological bureaucracy, with a resultant broken historical consciousness forming in their minds. Because they view life as a long row of randomly chained incidents and accidents, their motivations falter and they start to drift from one moment to the other. Secular time, as Kepnes (2006:115) reminds us, leaves us with Augustine's basic aporiai regarding the way in which we are trapped by our time concept. We are left with only the experience of time as a fleeting, ungraspable present moment that is destined to be encased in an irretrievable past. Trapped by the fleeting, ungraspable perpetuity of the present moment and enslaved by the exacting, mechanical deadline of the clock, we are robbed of the time of people - the time of relationships, the time of epic events, the time of exile and hope for a transformed and redeemed future. Trapped by the escalating implications of a system in which time is measured against money-making performance, we ask: is there a future? Or will our growing pessimism about the future lead us to retreat into a life of the 'perpetual present', drown ourselves in entertainment and seek any and every means of escape from reality? (Goheen 2008:105).

\section{An historical consciousness of incoherence in a world without a story}

The lack of an all-encompassing centre of integration in postmodern thought, can - in our view - leave people without a sense of coherence in life and the unfolding of its events, its purpose and its consummation. Without an overarching narrative in which the self might locate an enduring identity, the smaller narratives of human lives easily become fragmented into dislocated moments. It is the everyday experience of compartmentalised people, whose work lives are disconnected from their home and church lives, whose public speech does not coincide with their private convictions, whose youth and old age sit uncomfortably as disjointed bookends to an autonomous adulthood (BaderSaye 2006:94). The effect of this lacking coherence on the human mind can - in our view - be devastating. We crave not just an ending, but a good ending in which all manner of things shall be well (Hart 2007:173).

\section{The need for liturgical rituals that bring liberty and coherence}

As stated in the 'Introduction' this research intends to determine to what extent and in what sense honouring biblical perspectives on the concept of time (especially as it is expressed in the Easter moment) may be an important liturgical tool in activating the fullness of life that God intended for his people and for the world they live in. The brief exploration of current trends in Western conceptualisations of time and its impact on the human mind revealed two key issues that may be relevant in addressing our research question:
- To what extent can a new vision of the Easter moment be introduced in the ritual of the Eucharist in order to break the shackles of the exacting monotony of clock time and the unending perpetuity of the present moment?

- In what sense can temporal elements of ritual (such as remembrance, expression of living communion and anticipation) be aligned in order for the fragmented historical consciousness of the Western mind to be integrated meaningfully within a purposeful history in which God came to us in the past, is living amongst us in the present and will come to consummate us in the future?

\section{Exploring biblical perspectives on the concept of time}

\section{The twofold character of time against the backdrop of redemptive history}

Firstly, salvation is - in our view - bound to a continuous time process which is anchored in living remembrance of past events, develops in the present and is directed towards future consummation. This approach is based on a Trinitarian view of history initiated by God the Father, our Creator, liberated by God the Son, our Redeemer, and consummated by the Holy Spirit, and which differs from postmodern views on the nature of God and his involvement in this world and its time events, such as the bipolar view on the nature of God found in the theology of Marcus Borg (1994:102). In our approach, we view revelation and salvation as taking place along the course of an ascending timeline. Here, the strictly ascending-line conception of time in the New Testament must be defined over against the Greek cyclical conception and, also, over against all metaphysical conceptions in which salvation always lies in the 'beyond'. According to this interpretation of the Christian view, revelation and salvation actually 'occur' in a connected manner during the continuous time process.

Secondly, it is characteristic of the estimation of time against the backdrop of redemptive history that all points of the redemptive line are related to the one historical fact at the mid-point of history. This is a fact which, precisely in its unrepeatable character and with respect to the way in which it marks all historical events, may be viewed to be decisive for salvation (Cullmann 1965:32; Lathrop 1993:40). This fact comprises the historical event of the death and resurrection of Jesus Christ (Olsen 2006:313). In this perspective on time, there is a beginning (arge) and a purposeful development towards an end (telos) and as soon as the two points are distinguished and connected, the straight line is the more suitable illustration to use. This is the linear time concept (enriched by the ascending element of purpose). Time is marked by events, moments (that purposefully lead to consummation), rather than mere mechanical points and measured minutes on a line (Olsen 2006:312). The New Testament, in contrast with Judaism, holds the view that the mid-point, and 'breakthrough-point', of history no longer lies in the future but in the past. For Jesus, his coming signifies that the mid-point of the process has already been 
reached in his lifetime. He explains that the Kingdom of God has already come because he heals the sick, he checks the power of death and forgives sins. On the other hand, he also holds fast to the future character of this Kingdom (Cullmann 1965:83). The theologically important point in the preaching of the nearness of the Kingdom is the implicit assertion that, since the coming of Christ, we already stand in a new period of time and therefore the end has drawn nearer.

The doctrine of the incarnation, namely the eternal Christ becoming present in our time, carries with it a culmination of temporal dimensions. Eternity, or timelessness, has broken through into time. The Son of God knows neither beginning nor end. The man Jesus embraces, through becoming human, experiences both birth and death (Olsen 2006:313). The Book of Revelation defines Christ, temporally, in a juxtaposition: 'I am the Alpha and Omega, the First and the Last, the Beginning and the End' (Rv 22:13). Time begun and time finished are broken and redefined as the same event in relation to Christ (see also $\mathrm{Rv} 1: 8$ ). Revelation ends as it begins: with a statement of eternity, and Christ, understood temporally in the Gospels, is now understood eternally through the record of Revelation (Olsen 2006:320).

\section{Biblical terminology utilised in defining time}

The characteristic thing about kairos is that it has to do with a definite point or moment in time which has a fixed content, whilst aion designates duration of time, an extent of time (Byl 2001:24). These terms serve to characterise that time in which the redemptive history occurs. Jesus, himself, named his passion as his kairos at the time of the preparation for the Last Supper (Mt 26:18). On the other hand, chronos designates a period or space of time and refers to the time between special events and may be described as the time of sequence or chronology (Louw \& Nida 1988:639). Paul used the word chronos to describe the incarnation: 'But the time had fully come ...' (Gl 4:4) to stress the idea that historical events, moving through time, found completion at the moment Christ was born. Because of these linear events, occurring at different points in time, there was no greater moment for Christ to be born (Olsen 2006:313).

Christ, the incarnation of the divine revelatory Word and the mediator of all divine action, is so fully and closely connected with endless divine time that the author of the Epistle to the Hebrews can actually describe his nature in time terminology: 'Jesus Christ, the same yesterday and today and into the ages' (Heb 13:8). In submitting himself to time, the servant Lord becomes time's redeemer. The period between crucifixion and the parousia is time for the church to preach the gospel of the self-giving love in Christ and so facilitate a sharper response to the divine offer (Wainwright 1982:138).

\section{Humanity's enslavement to, and God's rule over, time}

In the Greek mind of antiquity, time was - in a sense - not conceived as a progressing line with a beginning and end, but rather as a circle. This conception of time implies that man is bound to time. Subjection to time is then experienced as a manifestation of enslavement; as a curse. Time spirals in an eternal circular course in which everything keeps recurring. This is also the case with people who do not believe in the liberation from the enslavement of time through the resurrection of Christ (Cullmann 1965:52). Their world exists and moves in time. Whatever natural human beings do or think, they do and think within time and under its definite power (Mantzarides 1981:64).

The God of history, who became flesh in a world where everything apparently repeats itself, liberated our time experience to proceed in the tension field between elements of the Kingdom of Heaven 'already' realised and those 'not yet' realised towards consummation. This temporal breakthrough of Jesus Christ into history gives time a goal, because it creates an eschatological horizon in which the believers can evaluate their lives as part of the Kingdom to come (Knight 2000:75, 76). God alone, therefore, rules over time, for he alone can survey it in its entire extension and evaluate it with measures which are as different from ours as the duration of a day is different from the duration of a thousand years (McKee 2003:17).

\section{The Easter moment and conceptualisation of time} Breaking the barrier of temporariness

Easter, as it is fulfilled in the death and resurrection of Christ, unlocks the moment when human eyes are opened to see the full meaning of Christ, to experience him and to meet God in him in a way God has never been met before. In this moment, Jesus, as the Son of God, breaks the barrier of time, space and death (Spong 1987:102, 103). The Easter moment was experienced by historic people in finite time and space and with life-changing intensity. It was a tremendous moment in which Jesus, who had died, became alive again in a way that defied description and broke temporal and physical barriers. It is the centre and heart of Christianity. The experience of the reality of the resurrection transformed the disciples into courageous people who braved the wrath and the persecution of the authorities to bear witness to the resurrection (BaderSaye 2006:109).

The Easter moment was a promise, a foretaste of that eschatological, post-historical moment of transformation into a new creation for both the living and the dead. Easter broke through and goes beyond the bounds of history. It is a transcendental event in which God raised Jesus from death into his own all-embracing dimension. The risen Jesus is a guarantee of the reality of the age to come when the dead shall be raised and the living shall be changed and the Kingdom of Heaven will dawn (Spong 1987:164). In his earthly life, Jesus had tested the barriers of human existence. He could penetrate beyond those inevitable human defensive barriers and explore life in its depths. In his death he had tested the ultimate barrier of human life. He opened to his followers, and to all who are or will be in Christ, a view and a means 
of passage into that realm forever (Wainright 1982:140). As Lord over the powers of death he had opened to all humanity the new world, the new vision and the transformed realm of new being. Believers could participate in that realm now, before death, before the end of the world. They could live in this world but by the power of the world to come.

\section{The ritual of the Eucharist as a clue to unlocking of the power of Christ}

The breaking of bread became the distinct liturgical act for Christians; the meeting place with the resurrected Lord of life. For those who believe in the sovereignty of God and understand liturgy as an encounter with a timeless and eternal God, the Eucharist, or communion with this God and each other, requires a shift in their understanding of time:

If we understand God as sovereign over all - including time - then our celebration of the Eucharist must extend beyond measured time and our appreciation of eternity and timelessness must inform our ritual for this meal.

(Olsen 2006:312)

The celebration of the Eucharist provides Christians with the central liturgical enactment of divine provision and thereby the central means of reshaping our perception of time as a mere empty utilitarian commodity to that of time as a gift filled with festivity in its highest form. The bread and wine are offered freely and the gathered people become guests at the great feast which they learn to receive with joy. The Christian community participates, if only for a moment, in the 'joyful consummation' of all things, that makes it possible for them to live during all other time in the broken reality of this world. This celebration of thanksgiving is the 'true time' that orders all other time (Bader-Saye 2006:110). Eucharistic rites recognise that there is an 'already', a 'not yet' and a 'one day' regarding our fellowship with God (Wainright 1982:143).

\section{The Eucharist and the time concept}

Liturgical action during the observance of the Eucharist (Lord's Supper) not only recalls the resurrection story, but also explores the world-changing personal and cosmic consequences of the resurrection. During the institution of the Lord's Supper, Jesus connects with two elements of the Passover ritual, namely the moment of the breaking of the bread and the serving of the third cup of wine, the cup of thanksgiving. In the New Testament, the word 'body' indicates, firstly, the person as creature of God in the totality of his or her being (cf. Rm 12:1). The word 'body' says: 'This is I, Myself, in my self sacrifice on the cross. I am doing this on behalf of and in place of you'. Jesus instituted the sign of the bread during the eating of the unleavened bread, the bread of affliction (Dt 16:3; Phillips 2003:195). In his body, in himself, in his self-sacrifice on the cross, he was the lamb that took away the sins of the world (Jn 1:29; Nurnberger 2007:162). In the same sense as the relation between the bread and the body of Christ, there is a relation between the cup of wine and the blood of Jesus. The word 'blood' in the Old and New Testament indicates that the life of someone is flowing away in a violent death. 'This is I, Myself, in my violent death' (see Mt 26:27, 28). In Jesus' death, connected with the new covenant, the expected and long awaited eschatological time breaks through (Panier 2005:60). The time of the new covenant is the time of the completely restored relationship between God and humankind. The blood of Jesus is the sole sign that the new people of God may join in the new covenant. The word of the breaking of the bread explains the aspects of temporal life from which the believers are redeemed, namely from death through sin. The word of the cup directs the goal of the salvation, namely the fulfilling joy of life in the new covenant (Phillips 2003:213).

Because of the fact that the crucified Jesus is the same person as the exalted Christ, the sacrament of the Eucharist focuses on the salvation acts of the cross not only in the sense of something that happened in the past, but the Eucharist ultimately calls us to faith in him as the living Christ (Phillips 2003:198). The living Christ uses bread and wine to serve us with the fruit that the suffering Jesus on the cross had fulfilled, so that we may experience communion with him. The living Christ himself is the host at the Eucharist. At the heart of the unique meaning of the Eucharist in the New Testament lies the living presence of Christ (Esser 2004:179). In this sense, it becomes particularly clear that the Sacrament of Communion is trusting and abiding in the presence of God (Old 2002:116). The Eucharist is not a meal of remembrance in honour of the deceased Jesus but a communion meal with the living Christ. In the communion with Christ, through the work of the Spirit, the partakers in the Eucharist receive the spiritual and heavenly life (Witvliet 2003:290). By means of the hidden operation of the Holy Spirit in the Eucharist we enjoy a genuine fellowship with Christ; and this fellowship is spiritual, but not spiritualistic, and real, but not realistic (Hesselink 2002:83).

Three aspects can be distinguished in the feast of the Eucharist: the aspect of remembrance, the aspect of proclamation and the aspect of expectance (Leithart 2000:158). The first aspect flows from Jesus' words: 'Do this in remembrance of me'. It is not a simple act of remembering with reference to what had happened on the cross. There is a power to memory and Paul uses this power to effect change in the Corinthians' perspective of the Eucharist. This memory does not only remember backwards, it also remembers forward: 'anamnesis' not only looks to the past action of God in Jesus' dying on the cross, it also looks to the future where we behold the nail-scars and see Christ in all his glory (Olsen 2006:322). In this regard, Moltmann (2008) says:

Without the memoria passionis Christi - the memory of Christ's passion - there is no Christian meditation vitae future - no Christian meditation on the future life; and conversely, without hope for the coming of Christ, the remembrance of Christ loses its power.

(Moltmann 2008:103)

Real presence - re-presenting past situations - brings a promise of communion: a uniting with each other and Christ, who has promised to be present in our midst. In the Eucharist 
we are compelled by the acts of eating the bread and drinking the wine to proclaim the death of Christ (Panier 2005:60). The Eucharist, in recalling and proclaiming the sacrifice of Jesus Christ, emphasises the implications of past events for the present context.

In Matthew 26:29, the following words are added to those instituting the Eucharist: 'I will not drink of this fruit of the vine from now on until that day when I drink it anew with you in my Father's Kingdom'. The believers may, in the celebration of the Eucharist, taste that in Christ the new covenant had been realised and that the end time has arrived (Panier 2005:57, 61). The Eucharist is a foretaste of the great feast in the fullness of the Kingdom of God. Christ is the future and in him the future became present. In the Eucharist the partakers may experience that joy (Wainright 1982:144). But we must also realise during the celebration of the Eucharist that the fullness of time has not yet come. The Eucharist is focused ultimately on the future of the fulfilled Kingdom. In the celebration of the Eucharist the windows to the future are revealed. Nowhere is the future so near and imminent than in the celebration of the Eucharist. The celebration of the Eucharist must therefore lead to the prayer for the Parousia (Wainright 1982:137).

In the worship service, the Eucharist points back to the crucified and Risen One and forward to him who comes at the end. But he who, in time, appears in the assembled congregation appears as the one sitting at the right hand of God, who has been crucified and has risen and will return. As such, he now offers the forgiveness of sin, which he has effected, and promises the completion, which he will bring (Cullmann 1965:169). In the Eucharist, past, present and future are bound together. We remember that our salvation is anchored in the past, we proclaim how the salvation must be experienced and we expect how the salvation will be completed in the future (Phillips 2003:204).

Combining past actions with future promise to define the present situation - redeeming time - creates a temporal moment beyond measurement. Now events are experienced in new ways, engagement with the divine brings new perspective to life and life is liberated from the measurement given by death. The Eucharist holds a unique position in this temporal moment: through a meal remembering past action and pointing to the future promise, our present gathering around the table combines past and future to bring about hope that transforms our present. No longer are we caught in a beginning-ending trap; no longer do we face the prospect of a periodic life, for the promise of life eternal comes through the grace of God (Olsen 2006:317). Wepener and Pauw (2004:114) find the essence of the temporal moment in the Eucharist in the reversal of death to life that is anchored in the death and resurrection of Christ. This Easter event transcends all human concepts of time and presents a time that cannot be cognitively perceived or categorised. Time changes by life's victory over death.

\section{Developing a practical theological theory for the function of the Easter moment in the Eucharist and its impact on transforming time conceptualisation}

The biblical concept of time, the Easter moment and its implications for the observance of the Eucharist ritual, can be important markers in transforming the problematic elements of the time concept by which God's people are enslaved, in which they drift and in which they become despondent. As a point of departure for describing the function of the Easter moment in transforming problematic elements in both traditional African and current Western time-concepts, we propose the first steps in the development of practical theological theory.

Firstly, a crucial indication of the praxis that needs to unfold in the Eucharist ritual begins with breaking the shackles of a mere quantitative, linear or cyclical conceptualisation of time and replacing it with the qualitative and eternal element that is opened through communion with the living Christ. When the Easter moment is experienced at the heart of the Eucharist ritual, a time concept trapped by the perpetual mechanics of the clock or by preoccupation with the past may be transformed to embrace elements of eternal life; in the process renewing the Christian community to view their lives and the life of the world they live in as a life destined for the immeasurable abundance and newness of eternal communion with God. Not life trapped in an endless circle of dying and death, but life out of death flows from the communion with Christ and time consciousness is liberated from its enslaving elements. A liberated humanity (from different cultural backgrounds) participating in this blessed life, may be united in ministering the power of the coming age, here and now; and fruit may grow from this ministry - fruit that will not wither away or disappear beneath the sands of time.

Secondly, to anchor fragmented lives lived out in a world without a story, or lives that have become disconnected to the future, in the narrative of God, who reveals himself as the One that was, is and will come, comprises another crucial temporal element, which needs to be re-affirmed in the praxis of the ritual of the Eucharist. The elements of remembrance, communion and anticipation in the Eucharist ritual should be aligned in such a way that the historical consciousness of humanity can be anchored in a history in which God came to us in the past, is living amongst us in the present, and will come to consummate us (bring our lives to a good ending) in the future. We believe that this will give us a sense of belonging, a sense of purpose and a sense of living hope, bringing the joy of a life worth living to all.

\section{Acknowledgements Competing interests}

The authors declare that they have no financial or personal relationship(s) which may have inappropriately influenced them in writing this paper. 


\section{Author contributions}

R.S. Letšosa researched and wrote the section entitled: 'Perspectives on the time concept in a traditional African context', whilst F.W. De Wet researched and wrote 'Perspectives on the time concept in current Western culture' and B.J. De Klerk researched and wrote 'Exploring biblical perspectives on the concept of time'. All three authors collaborated in writing the concluding sections of the article.

\section{References}

Bader-Saye, S., 2006, 'Figuring time: Providence and politics', in R. Rashkover \& C.C. Pecknold (eds.), Liturgy, time and the politics of redemption, pp. 91-111, Eerdmans, Grand Rapids, MI.

Borg, M.J., 1994, Meeting Jesus again for the first time, Harper, New York, NY.

Byl, J., 2001, God and cosmos: A Christian view of time, space and the universe, Banner of Truth, Edinburgh.

Cullmann, O., 1965, Christ and time. The primitive Christian conception of time and history, SCM Press, London.

Esser, H.H., 2004, 'Freiheit zu okumenischer eucharistischer Gastfreundschaft. Zur offenen Kommunion: Theological-ecumenical', Acta Theologica: Teologiese, historiese en Wetenskaps-Filosofiese Stusies binne Reformatoriese Kader, Supplementum 5, 172-183.

Goheen, M.W., 2008, Living at the crossroads - An introduction to Christian worldview Baker Academic, Grand Rapids, MI.

Hart, T.A., 2007, 'The sense of an ending: Finitude and the authentic performance of life', in T.A. Hart \& S.R. Guthrie (eds.), Faithful performances - Enacting Christian tradition, pp. 167-186, Ashgate, Aldershot.

Hesselink, I.J., 2002, 'The role of the Holy Spirit in Calvin's doctrine of the sacraments', Acta Theologica: Essentialia et Hodierna, Supplimentum 3, 66-88.

Kagame, A., 1996, 'The empirical appreciation of time and the conception of history in Bantu thought', in E. Parker \& K.M. Kalumba (eds.), African philosophy, pp. 82-90, Prentice Hall, Upper Saddle River, NJ.

Kepnes, S., 2006, 'Rosenzweig's liturgical reasoning as response to Augustine's temporal aporias', in R. Rashkover \& C.C. Pecknold (eds.), Liturgy, time and the politics of redemption, pp.112-123, Eerdmans, Grand Rapids, MI.

Knight, D., 2000, “'Jenson on time”", in C.E. Gunton (ed.), Trinity, time and church A response to the theology of Robert W. Jenson, pp. 70-88, Eerdmans, Grand Rapids, MI.

Lathrop, G., 1993, Holy things: A liturgical theology, Augsburg Fortress, Minneapolis, $\mathrm{MN}$
Leithart, P.J., 2000, Blessed are the hungry. Meditations on the Lord's Supper, Canon Press, Moscow.

Louw, J.P. \& Nida, E.A., 1988, Greek-English lexicon of the New Testament based on semantic domains, vol. 1, United Bible Societies, New York, NY.

Mantzarides, G.I., 1981, 'The divine liturgy and the world', Greek Orthodox Theological Review 26(1\&2), 62-70.

Mbiti, J., 1969, Africa religions and philosophy, Praeger, New York, NY.

McKee, E.A., 2003 'Reformed worship in the sixteenth century', in L. Vischer (ed.) Worship in reformed churches past and present, pp. 1-20, Eerdmans, Grand Rapids, MI.

Moltmann, J., 2008, A broad place. An autobiography, Fortress Press, Minneapolis, $\mathrm{MN}$.

Nouwen, H.J.M., 1972, The wounded healer, Doubleday, New York, NY.

Nurnberger, K., 2007, 'Ancestors and spirits in the light of Luther's theology', Dutch Reformed Theological Journal 48(1\&2), 150-168.

Nyirongo, L., 1993, The gods of Africa or the God of the Bible?: The snares of African traditional religion in Biblical perspective, Institute for Reformational Studies Potchefstroom University for Christian Higher Education, Potchefstroom.

Old, H.O., 2002, Worship. Reformed according to Scripture, Westminster John Knox Press, Louisville, KY.

Olsen, G., 2006, 'Time and expression in the Eucharist', Worship 80(4), 310-326.

Panier, L., 2005, 'Bread and cup. Word given for a time of absence', in C. Boureux, J.M. Soskice \& L.C. Susin (eds.), Hunger, bread and Eucharist, pp. 48-65, SCM Press, London.

Phillips, D., 2003, 'The Lord's Supper: An overview', in P.G. Ryken, D.W.H. Thomas \& J.L. Duncan III (eds.), Give praise to God, pp. 193-221, P\&R Publishing, Phillipsburg,

Spong, J.S., 1987, The Easter moment, Harper \& Row, San Francisco, CA

Turaki, Y., 1993, 'Human dignity, identity and reconciliation', in M. Waijaki, Y. Turaki, B.J. Van der Walt \& P. Kasenene (eds.), Visions of man and freedom in Africa, pp. 9-29, Institute for Reformational Studies - Potchefstroom University for Christian 9-29, Institute for Reformational Stud
Higher Education, Potchefstroom.

Van der Walt, B.J., 2003, Understanding and rebuilding Africa: Form desperation today to expectation for tomorrow, Institute for Contemporary Christianity in Africa, Potchefstroom.

Van Zyl, D.C., 2007, 'A square peg in a round hole? Questioning the use of the concept of time in teaching the Old Testament in Africa', Scriptura 94, 143-151.

Wainright, G., 1982, 'Sacramental time', Studia Liturgica 14(2-4), 135-146.

Wepener, C. \& Pauw, C., 2004, 'Terug na die toekoms: Oor die samehang tussen rituele tyd en identiteit', Scriptura 85, 110-122.

Witvliet, J.D., 2003, Worship seeking understanding, Baker Academic, Grand Rapids, 